\title{
Peningkatan Kompetensi Web Design Peserta Didik Menggunakan Metode "Rekam Layar" Di LKP Elite English School
}

\author{
Khoiru Nurfitri \\ Universitas Muhammadiyah Ponorogo \\ Jl. Budi Utomo No 10 Ponorogo \\ nurfitrikhoiru9@gmail.com
}

\begin{abstract}
There are 3 aspects of competency that must be achieved by students of computer programs in Elite English school of Ponorogo. The 3 aspects include knowledge, skills and attitudes. In Web Design class of computer programs the average student only excels at one aspect of competency. The unachievement is due to the lack of direct observation by the instructor which causes students to not follow the practice in full. The instructor has difficulty if they have to accompany each student directly because of the limited time and many students in the class. This study aims to apply the rekam layar method so that students are able to achieve all three aspects of competence. The screen recording method is a method that aims to make observations of students using computer software. This study uses the method of direct observation and interviews which lasted for two months. Rekam Layar learning method has been proven to be able to help students personally observe the process effectively. Student competency can be increased using the Rekam Layar learning method.
\end{abstract}

Keywords: learning method, Web design, rekam layar, elite English School, Ponorogo

\begin{abstract}
Abstrak
Terdapat 3 aspek kompetensi yang harus dicapai oleh peserta didik program komputer di Elite English school Ponorogo. Adapun 3 aspek tersebut yaitu meliputi pengetahuan, keterampilan, dan sikap. Pada program komputer kelas Web Desain rata-rata peserta didik hanya unggul pada salah satu aspek kompetensi. Ketidaktercapaian tersebut dikarenakan kurangnya pengamatan secara langsung oleh instruktur yang menyebabkan adanya peserta didik yang tidak mengikuti praktek secara penuh. Instruktur mengalami kesulitan jika harus mendampingi masing-masing peserta didik secara langsung karena terbatasnya waktu dan jumlah peserta didik dalam kelas. Penelitian ini bertujuan untuk menerapkan metode rekam layar agar peserta didik mampu mencapai ketiga aspek kompetensi. Metode rekam layar merupakan metode yang bertujuan untuk melakukan pengamatan terhadap peserta didik menggunakan perangkat lunak komputer. Penelitian ini menggunakan metode observasi langsung dan wawancara yang berlangsung selama dua bulan. Metode pembelajaran Rekam Layar telah terbukti dapat membantu proses pengamatan peserta didik secara personal dengan efektif. Kompetensi peserta didik dapat meningkat menggunakan metode pembelajaran Rekam Layar.
\end{abstract}

Kata kunci: Metode Pembelajaran, Web desain, rekam layar, elite English School, Ponorogo

\section{PENDAHULUAN}

Tujuan dari pembelajaran web design peserta didik di Elite English School Ponorogo yaitu menghasilkan kompetensi di bidang web design. Tercapainya kompetensi ditandai dengan tercapainya tiga aspek pembelajaran yang terdiri dari pengetahuan, keterampilan, dan sikap. Hasil 
pembelajaran di LKP Elite English School program kursus komputer pembuatan Web menunjukkan bahwa tujuan utama dari pembelajaran web design belum tercapai. Banyak peserta didik hanya unggul dari salah satu aspek saja. Pernyataan tersebut merupakan simpulan dari hasil pembelajaran peserta didik. Dampaknya peserta didik kesulitan mengembangkan ilmu tentang web design setelah selesai mengikuti pembelajaran. Secara otomatis daya saing lokal maupun interlokal mereka juga akan berkurang.

Mengacu pada permasalahan di atas maka peningkatan kompetensi harus dilakukan. Peserta didik yang terampil dan kompeten dapat tercipta apabila pembelajaran dilakukan dengan proses yang baik. Dalam proses pembelajaran web design, kegiatan praktek merupakan suatu hal yang mutlak. Pengamatan instruktur terhadap peserta didik yang sedang berproses juga merupakan suatu hal yang sangat penting. Pengamatan dilakukan untuk mengetahui sejauh mana peserta didik mampu menyerap materi dan bisa mengaplikasikannya. Dalam hal ini instruktur harus menjadi pengamat yang baik. Dengan melakukan pengamatan maka capaian pembelajaran oleh peserta didik dapat diketahui. Selama ini pengamatan dilakukan secara klasikal sehingga hasil pengamatan kurang efektif. Untuk mencapai hasil pengamatan belajar peserta didik seharusnya dilakukan secara personal. Kenyataannya hal tersebut sangat sulit dilakukan mengingat singkatnya waktu dalam pembelajaran.

Di jaman modern seperti ini keterbatasan waktu bukanlah merupakan sesuatu hal yang sulit diatasi. Teknologi saat ini berkembang sangat pesat. Perangkat lunak dan perangkat keras komputer juga mengalami perkembangan sangat pesat. Semua teknologi yang hadir bertujuan untuk mempermudah aktivitas manusia. Strategi Pembelajaran Inovatif Berbasis TIK juga sudah banyak dilakukan [1]. Saat ini telah tersedia perangkat lunak komputer baru yang dapat digunakan untuk merekam segala aktivitas di layar monitor komputer.

Hadirnya perangkat lunak perekam layar monitor dapat menyelesaikan permasalahan yang sedang dihadapi. Terdapat beberapa jenis perangkat perekam layar, adapun yang digunakan oleh peneliti adalah Camtasia. Perangkat lunak ini dapat digunakan untuk melakukan pengamatan peserta didik secara personal. Singkatnya waktu dalam pembelajaran tidak lagi menjadi kendala saya dalam melakukan pengamatan peserta didik. Selain itu Camtasia tidak berbayar dan dapat pula kita menggunakan software perekam lain.cPenelitian ini bertujuan untuk menerapkan metode rekam layar dalam melaksanakan pengamatan secara langsung terhadap peserta didik.

\section{METODOLOGI PENELITIAN}

Tahapan pembelajaran yang dilakukan oleh instruktur Elite English School secara berurutan sebagai berikut: pembukaan, apersepsi, penyampaian tujuan dan manfaat, materi, demonstrasi, aplikasi dan evaluasi. 
Masalah yang sering dihadapi pada saat pembelajaran yaitu tahap demonstrasi, aplikasi dan evaluasi yang tidak berjalan sesuai dengan tujuan pembelajaran. Masalah tersebut menghambat peserta didik dalam mencapai tiga aspek pembelajaran: pengetahuan, keterampilan, dan sikap. Dalam pembelajaran selain mereka harus memiliki pengetahuan yang baik juga harus bisa mengaplikasikan pengetahuannya dengan sikap yang baik. Penilaian pada pembelajaran web design menggunakan interval satu sampai 4 (1-4). 1 adalah nilai minimum dan 4 adalah nilai maksimum. Kompetensi peserta didik rata-rata kurang dari 2. Secara otomatis capaian angka tersebut sangat minim. Akibatnya peserta didik tidak memiliki ketrampilan yang mumpuni. Hal tersebut akan membuat mereka kesulitan mengembangkan ilmu serta mengimplementasikannya.

Permasalahan di atas sebenarnya dapat diatasi apabila pengamatan/ pengawasal dilaksanakan dengan efektif. Pengamatan yang dilakukan seharusnya secara detail. Masing-masing peserta didik harusnya mendapatkan pendampingan. Khususnya untuk peserta didik yang sangat mengalami kesulitan dalam pemahaman ilmu maupun kegiatan praktek. Pada kenyataannya proses pengamatan sulit dilakukan karena keterbatasan waktu dan jumlah peserta didik dalam kelas.

Saat menemukan masalah-masalah di atas, saya mencoba menyelesaikan masalah dengan melakukan beberapa langkah. Langkah peneliti yaitu:

(1) Mengidentifikasi masalah,

(2) Menciptakan dan metode baru, dan

(3) Mendapatkan hasil. Berikut skema langkah yang saya lakukan:

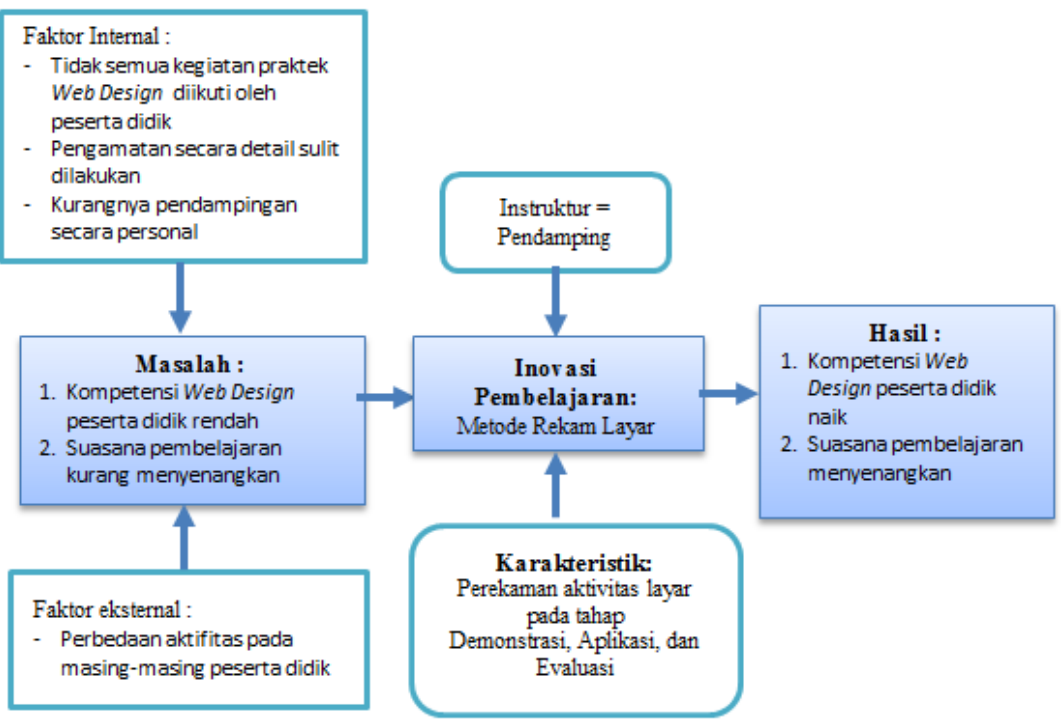

Gambar 1. Skema Strategi Penyelesaian Masalah 


\subsection{Faktor Internal}

a) Tidak semua kegiatan praktek web design diikuti oleh peserta didik. Pada saat proses pembelajaran web design pasti ada kegiatan praktek. Kadang-kadang peseta didik hanya melihat temannya melakukan praktek. Pada saat ditanya instruktur mereka menjawab bahwa praktikumnya jadi satu dengan temannya. Secara otomatis kompetensi keterampilannya tidak dapat dinilai.

b) Pengamatan secara detail sulit dilakukan. Pengamatan instruktur terhadap peserta didik yang sedang berproses merupakan suatu hal yang sangat penting. Untuk mencapai hasil pengamatan belajar peserta didik seharusnya dilakukan secara personal. Kenyataannya hal tersebut sangat sulit dilakukan mengingat singkatnya waktu dan jumlah peserta didik dalam kelas.

c) Kurangnya pendampingan secara personal.

Instruktur akan merasa kesulitan untuk melakukan pendampingan apabila peserta didik tidak meminta pendampingan. Selain itu intruktur tidak mengetahui kesulitan peserta didik secara detail.

\subsection{Faktor Eksternal}

Perbedaan aktifitas pada masing-masing peserta didik. Peserta didik memiliki aktifitas dan kesibukan masing-masing. Peserta didik yang terlihat capek biasanya pada kegiatan praktek hanya gabung dengan teman dekatnya.

\subsection{Masalah}

a) Kompetensi web design peserta didik rendah.

Kompetensi pembelajaran web design mengandung tiga aspek yaitu pengetahuan, keterampilan, dan sikap. Kebanyakan dari peserta didik hanya memenuhi tiga aspek saja. Ketiga aspek seharusnya dapat tercapai untuk mendapat hasil pembelajaran yang maksimal.

b) Suasana pembelajaran kurang menyenangkan.

Suasana kelas pada pembelajaran web design terasa kurang menyenangkan. Beberapa peserta kurang antusias mengikuti pembelajaran. Hal tersebut ditandai dengan kehadiran peserta yang tidak sesuai dengan waktu, kurangnya peserta didik yang bertanya, beberapa siswa mengobrol sendiri dikelas.

c) Inovasi Pembelajaran.

Setelah melakukan identifikasi masalah maka saya membuat metode pembelajaran baru yaitu Rekam Layar Peserta Didik. Secara umum pengertian dari metode pembelajaran ini adalah perekaman layar monitor pada kegiatan demonstrasi, aplikasi, dan evaluasi. Dalam pembelajaran ini instruktur bertindak sebagai pendamping peserta didik. Pendampingan dilakukan pada saat aplikasi oleh peserta didik. 
Berikut adalah prosedur dalam penerapan metode pembelajaran "Rekam Layar" pada pembelajaran web design:

1. Perencanaan

Perencanaan merupakan langkah awal dalam melakukan pembelajaran. Ada beberapa langkah dalam metode pembelajaran Rekam Layar untuk meningkatkan kompetensi web design peserta didik di LKP Elite English School, yaitu:

a. Persiapan peserta didik

Sebelum melaksanakan pembelajaran tentunya saya harus menyiapkan peserta didik. Persiapan peserta didik terdiri dari identitas peserta didik, jumlah, dan ketentuan yang harus dipenuhi peserta didik. Terdapat beberapa ketentuan yang harus dipenuhi oleh calon peserta didik seperti memenuhi ketentuan batas umur, dapat mengoperasikan komputer, dan lain-lain.

b. Persiapan Ruang

Sebelum melakukan metode pembelajaran Rekam Layar, persiapan ruang harus dilakukan dengan cermat. Ruangan harus nyaman, sirkulasi udara berjalan dengan baik, serta dapat memuat jumlah peserta yang telah ditentukan.

c. Persiapan Materi

Materi dalam pembelajaran web design secara umum merancang dan membangun website dari sisi client (front-end) serta membuat basis data berdasarkan standar yang telah ditetapkan dan sesuai dengan spesifikasi pengguna.

d. Persiapan Silabus

Komponen silabus terdiri dari standart kompetensi, kompetensi dasar, indikator, alat/sumber, dan penilaian.

e. Persiapan RPP

Komponen rencana pembelajaran web design menggunakan metode pembelajaran Rekam Layar yaitu:

1) Identitas pelajaran (nama pelajaran, waktu/ banyaknya jam pertemuan yang dialokasikan)

2) Kompetensi dasar dan indikator yang akan dilaksanakan.

3) Strategi pembelajaran (menggunakan metode pembelajaran Rekam Layar)

4) Alat dan media yang digunakan untuk memperlancar pencapaian kompetensi.

5) Penilaian dan tindak lanjut

f. Persiapan hardware dan software

2. Pelaksanaan

a. Pembukaan

Tahap awal dalam pembelajaran pada umumnya yaitu pembukaan. Pembukaan diawali dengan salam, absensi peserta, sampai dengan memberi motivasi. 
b. Penyampaian Judul Pembelajaran

Instruktur menyampaikan judul pembelajaran bertujuan agar peserta didik mengerti tentang materi apa yang akan dibahas pada saat pertemuan tersebut.

c. Sampaikan Tujuan dan Manfaat Pembelajaran

Sebelum masuk materi pembahasan saya menyampaikan tujuan pembelajaran. Tahap ini bertujuan agar peserta didik mengerti tujuan pembelajaran yang akan mereka capai pada pertemuan tersebut. Dengan begitu mereka mempunyai bayangan akan kemana arah pembelajaran tersebut. Selain itu, supaya peserta didik tidak kesulitan dalam mengikuti proses pembelajaran. Begitu juga dengan manfaat pembelajaran, peserta didik akan mengetahui manfaat apa yang akan didapat setelah instruktur menyampaikan manfaat pembelajaran.

d. PenyampaianTeori

Pada langkah kedua, setelah siswa mengetahui tujuan dan manfaat dari pembelajaran kemudian instruktur menyampaikan teori. Teori yang disampaikan haruslah sesuai dengan tujuan yang akan dicapai dan harus mengarah kepada tujuan pembelajaran.

e. Demonstrasi dengan Camtasia

Setelah materi saya sampaikan secara teori, maka selanjutnya yaitu saya melakukan demonstrasi atas teori yang telah saya sampaikan. Perangkat lunak Camtasia harus dinyalakan terlebih dahulu. Ini bertujuan untuk mendokumentasikan hasil demontrasi instruktur supaya dapat disebarkan kepada peserta didik. Sehingga peserta didik dapat memutar video kembali setiap saat kapanpun mereka membutuhkan. Pada tahap ini peserta didik hanya berperan sebagai penglihat dan pendengar saja.

f. Aplikasi dengan Camtasia

Pada tahap ini peserta didik mempraktekkan kembali materi yang telah saya demonstrasikan. Pada tahap ini peserta didik harus menyalakan Camtasia pada komputer mereka. Camtasia akan merekam layar monitor yang digunakan oleh masing-masing peserta. Camtasia bisa dimatikan setelah mereka selesai melalui tahap ini. Bagi peserta yang mengalami kesulitan dalam pengerjaannya akan didampingi instruktur. Hasil rekaman harus disimpan dalam bentuk video dan kemudian dikumpulkan kepada instruktur menggunakan fleshdisk atau perangkat lain yang dapat digunakan untuk sharing data.

g. Evaluasi

Evaluasi pada metode pembelajaran Rekam Layar dilakukan dalam dua bentuk:

a) Tulis

Evaluasi secara tertulis dilakukan pada pertemuan terakhir dengan sifat ujian. 
b) Praktek

Evaluai secara praktek dilakukan setiap kali pertemuan dan pertemuan terakhir. Pada saat evaluasi praktek peserta didik harus menyalakan Camtasia. Peserta didik boleh mematikan Camtasia apabila proses evaluasi sudah selesai. Video hasil rekaman harus dikumpulkan kepada instruktur setelah mereka selesai melakukan evaluasi praktek.

\section{HASIL DAN PEMBAHASAN}

Pada metode Rekam Layar ini peneliti lebih menekankan kepada pengamatan guna meningkatkan pencapaian kompetensi peserta didik. Setelah menerapkan metode pembelajaran Rekam Layar saya mendapatkan beberapa perubahan hasil pembelajaran yaitu:

a) Pengamatan meningkatkan kompetensi.

Saya dapat meningkatkan kompetensi peserta didik dengan menekankan pengamatan personal terhadap peserta didik. Dengan dibantu perangkat lunak Camtasia maka pengamatan yang saya lakukan berjalan dengan sangat efektif. Dari hasil pengamatan saya juga dapat melakuakan penilaian dengan lebih mudah. Masing-masing peserta terlihat berbedabeda caranya dalam mengerjakan tugas prakteknya. Kompetensi pengetahuan, keterampilan, dan sikap dapat meningkat secara gradual.

b) Suasana pembelajaran menyenangkan

Suasana dalam pembelajaran web design terlihat menyenangkan dengan adanya pemutaran video rekaman di akhir pembelajaran. Peserta didik lebih merasa tertantang untuk mengingat dan memperhatikan dengan baik semua materi yang disampaiakan oleh instruktur. Hal ini dikarenakan pada umumnya peserta didik menginginkan proses perekaman aktifitas mereka berjalan lancar.

c) Peserta aktif pada sesi Tanya jawab

d) Kompetensi mereka dapat tercapai dengan baik. Pengetahuan diserap dengan cara menghafal, keterampilan dilaksanakn dengan metode perekaman akan membuat mereka lebih jeli dalam pengerjaan, serta sikap mereka akan terjaga karena adanya perekaman aktvitas layar monitor mereka. Motivasi belajar web design siswa meningkat. Dengan adanya perekaman aktivitas maka mereka merasa lebih semangat dalam mengikuti pembelajaran web design karena harus menampilkan yang terbaik. 
Jurnal Sains Komputer \& Informatika (J-SAKTI)

Volume 3 Nomor 2 September 2019, pp. 401-410

ISSN:2548-9771/EISSN:2549-7200

http://tunasbangsa.ac.id/ejurnal/index.php/jsakti

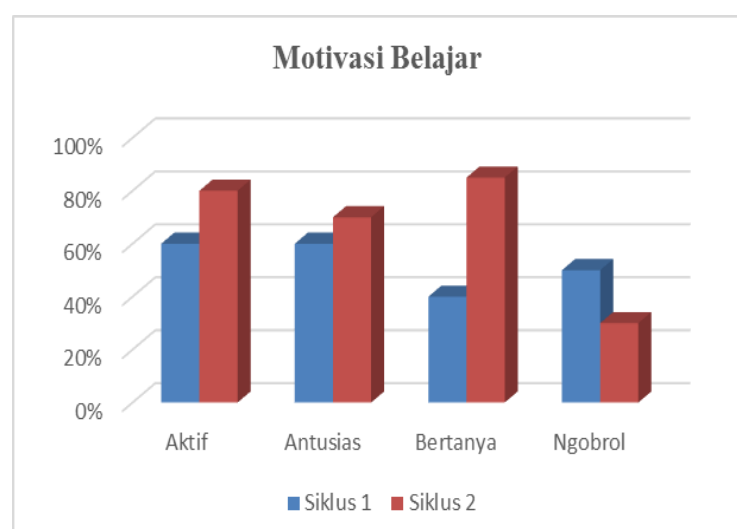

Gambar 2. Grafik Peningkatan Motivasi belajar

e) Tidak ada kecemburuan sosial pada metode pembelajaran ini, karena semua peserta didik akan diperhatikan dan diamati. Peserta didik yang mengalami kesulitan dalam pengerjaannya akan dibantu oleh instruktur.

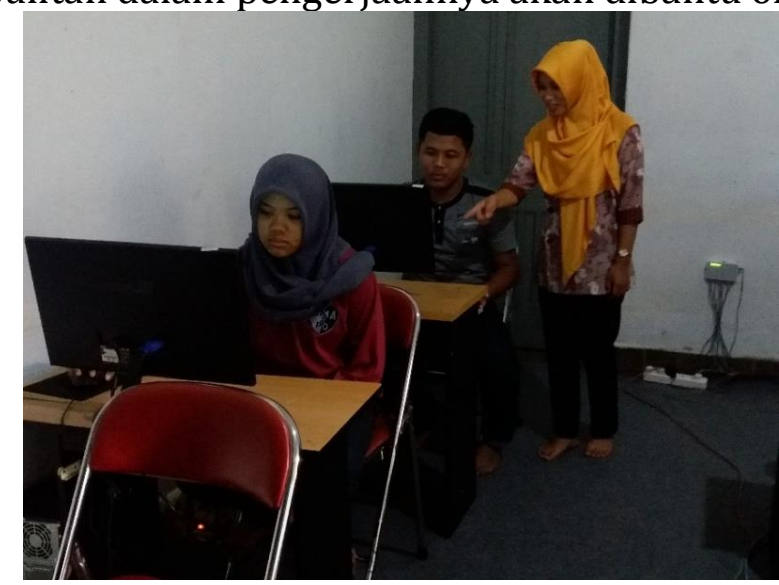

Gambar 3. Pendampingan peserta didik

f) Nilai peserta didik mengalami peningkatan dengan metode pembelajaran ini.

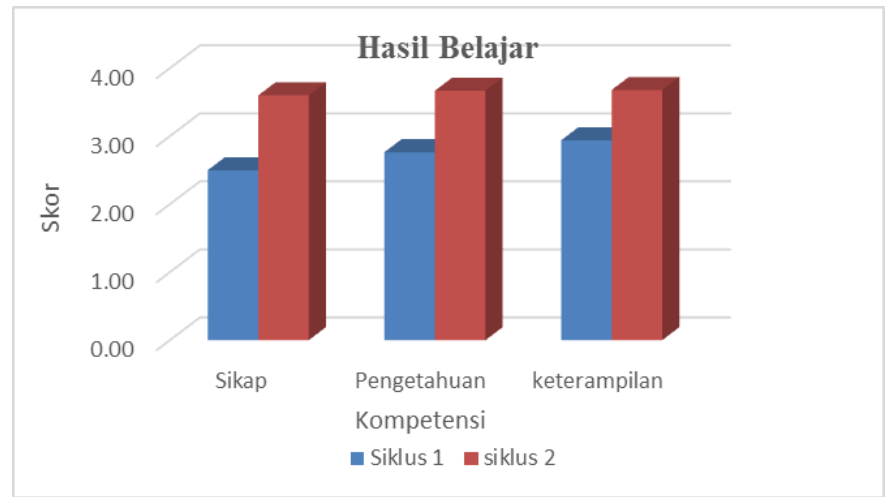

Gambar 4. Grafik Peningkatan hasil belajar 
g) Evaluasi dilakukan setiap kali pertemuan yang bersifat terbuka sehingga membuat peserta didik memiliki kemauan untuk memperbaiki kesalahan yang dilakukan

Berikut adalah keunggunalan dan keunikan metode rekam layar dibanding dengan metode konvensional:

1. Keunggulan

a. Semua kegiatan belajar mengajar pada layar monitor masing-masing peserta didik dapat terekam.

b. Hasil rekaman dalam bentuk video sehingga dapat disimpan dan diputar kembali setiap saat.

c. Hasil rekaman dikumpulkan kepada instruktur sehingga instruktur dapat melakukan pengamatan melalui video rekaman tersebut kapanpun.

d. Video hasil rekaman dapat diputar sendiri oleh instruktur atau diputar di depan peserta didik untuk penguatan, perbaikan, maupun evaluasi pembelajaran.

e. Peserta tidak perlu menggunakan buku untuk mencatat materi yang telah disampaikan. Hasil video rekaman dari instruktur dapat mereka copy dan digunakan untuk belajar di luar kelas sekaligus untuk dokumentasi pembelajaran. Namun tidak ada larangan apabila peserta menghendaki untuk mencatat di buku.

f. Motivasi peserta didik dalam belajar web design akan meningkat karena mereka mengetahui bahwa masing-masing layar monitor terekam sehingga akan berusaha mengerjakan tugas dengan sebaikbaiknya.

g. Sesi tanya jawab akan lebih hidup karena mereka mengetahui bahwa hasil pekerjaan mereka akan terekam, sehingga mereka berusaha aktif

h. Suasana kondusif dapat tercipta pada saat penyampaian materi dan demonstrasi.

2. Keunikan

Sesuatu yang menjadi keunikan pada metode pembelajaran "Rekam Layar" adalah rekaman layar monitor masing-masing siswa. Biasanya perangkat lunak Camtasia digunakan untuk merekam layar monitor yang bertujuan untuk membuat tutorial [2]. Banyak guru atau tenaga pendidik yang menggunakan perangkat lunak ini sebagai media penyampaian materi. Dalam bentuk video tutorial seorang guru dapat menyampaikan materi kepada peserta didik sehingga beban mengajar guru dapat tergantikan oleh perangkat lunak ini [3]. Tetapi pada metode pembelajaran Rekam Layar bukan hanya instruktur yang menggunakan tetapi juga peserta didik. Dalam hal ini penggunaan camtasia oleh instruktur dan peserta dilakukan di ruang kelas pada saat proses kegiatan belajar mengajar. 


\section{SIMPULAN}

Metode pembelajaran Rekam Layar telah terbukti dapat membantu proses pengamatan peserta didik secara personal dengan efektif. Kompetensi peserta didik dapat meningkat menggunakan metode pembelajaran Rekam Layar. Peserta didik menjadi lebih bersemangat sehingga suasana kelas menjadi Motivasi peserta didik meningkat menggunakan metode pembelajaran Rekam Layar.

\section{DAFTAR PUSTAKA}

[1] Gora,Winastwan dan Sunarto, "PAKEMATIK Strategi Pembelajaran Inovatif Berbasis TIK", Elex Media Komputindi, 2010.

[2] Jubilee, Enterprise, "Membuat Video Tutoria Menggunakan Camtasia", Elex Media Komputindi, 2015.

[3] Demyan, David B, E., "E-learning with Camtasia Studio" PACKT Publishing. 